\title{
Floristic diversity and Ecology of EpilithicDiatoms of the ChottChergui wetland (North-West of Algeria)
}

\author{
Negadi $M^{1^{*}}$, Ait Hammou $M^{1}$, Miara M.D ${ }^{1}$, Bendif $\mathbf{H}^{2}$, Blake $\mathbf{P}^{3}$ \\ 1 Department and Faculty of Nature and Life Sciences. Laboratory of Agro Biotechnology and \\ Nutrition in Semi-arid Areas. Ibn Khaldoun University of Tiaret, Algeria. 14000. DZ \\ 2 Natural and Life Sciences Department, Faculty of Sciences, University of M'sila, Algeria. \\ 3 Yale University, Department of Earth and Planetary Sciences.
}

*Corresponding Author: Mohamed Negadi, University of Tiaret, Algeria Email:
mohamed.negadi14@gmail.com

\begin{abstract}
This study is a phytoecological approach aimed to improve the knowledge on diatoms and their ecology in the wetland of ChottChergui in the northwesternregionof Algeria.For this work, 60 samples of solid substrates containing the epilithic diatom flora were collected in the field using a subjective method. The identification of diatom taxa was carried out according to a standard protocol while using pertinentliteraturethat specialized guides. At the level of the 5 sampling sites, water physicochemical parameters that could influence the distribution of diatoms were measured. The results obtained made it possible to recognize 36 diatom taxa belonging to 12 families, of which, the most dominant were Naviculaceae, Surirellaceae and Bacillariaceae. The calculated biodiversity indices (Shannon's H and equitability revealed a low taxonomic richness which will probably be explained by the dominance of the typical brackish water taxa such as Mastogloiabraunii, Campylodiscusclypeus , and Navicymbulapusilla. We were also able to characterize the distribution of identified taxa according to the physicochemical parameters of each site. Furthermore, the attraction of the diatomic communities to saprobia shows the predominance of the two classes: $\alpha$-mesosaprobic and $\beta$-mesosaprobe during the two seasons of fall and spring. Canonical correspondence analysis revealed that the distribution of diatom communities is positively correlated with conductivity and temperature. Some species like Navicymbulapusilla, show a significant resistance to anthropogenic eutrophication.
\end{abstract}

Keywords: Algae, Epilithic Diatoms, Ecology, ChottChergui,Tiaret, Wetland.

\section{Introduction}

Diatoms (Bacillariophyceae) are major group of unicellular algae that have been widely used over the past fifty years as bioindicators in the ecological assessment of rivers around the World. Diatoms are very sensitive to changes in nutrient concentrations and organic pollution (Prateek et al., 2016). The taxonomy of diatoms is complicated and their mode of reproduction is particular because reproduction is generally sexual. However,there can be individual division,causing a subtle alteration in shape. In general, they are identified through the morphology of cells which are characterized by geometric shape and their internal structures.

Work on Algerian diatoms began more than a century ago (Montagne, 1846; Ehrenberg 1854).Some studies were carried out during the 1970s (Baudrimont, 1970-1974) on the inventory of freshwater diatoms. Recent studies conducted by (Lange-Bertalot et al., 2009; Chaib et al., 2011, 2012; Nehar et al., 2015; El Haouati et al., 2015; Negadi et al., 2018) have made it possible to relatively gain moreunderstanding of this flora.

Unlike the vascular flora, there is a paucity in the study oftheNorthAfrican cryptogamic flora, primarily those in Algeria (Ait Hammou, 2015). Research and field data on diatomsare still incomplete, especially their taxonomy and ecology (Negadi et al, 2018). For this reason,ourstudyseeks to characterize the diversity and ecology of the epilithic diatoms existing in the ChottChergui wetland in the north-west of Algeria.This region is very rich in salt, brackish and hot thermal water resources and constitutes the largest natural wetland of this type in North Africa after the ChottDjerid in Tunisia.The study of the diatoms diversity of this region is likely to increase the interest of conservation and protection of this 
wetland as part of an environmentally sustainable agenda. Furthermore, the obtained dataon the ecology of these taxa could provide more information on their local and regional distribution.

\section{Study area}

The ChottChergui region $\left(0^{\circ} 45^{\prime}\right.$ to $0^{\circ} 55^{\prime} \mathrm{E}, 34^{\circ} 25^{\prime}$ to $\left.34^{\circ} 30^{\prime} \mathrm{N}\right)$ is located in the NorthWest of Algeria in the semi-arid steppe highlands. With an area of $855500 \mathrm{~km}^{2}$ (varies according to precipitation), its width is approximately $160 \mathrm{~km}$, while the maximum altitude is $1108 \mathrm{~m}$. Administrative records show that this area primarily includes the southern part of the wilaya (province) of Tiaret, which represents the eastern part of the wetland with an area of around 50000ha (CFT, 2016). The communes of SidiAbd Rahman and that of Chehaima house the majority of the Chott area.

This region is located in a steppe zone comprising salty, brackish water as well as a halophyte flora and fauna well adapted to the semi-arid climate.

\section{Material and methods}

\section{Sampling}

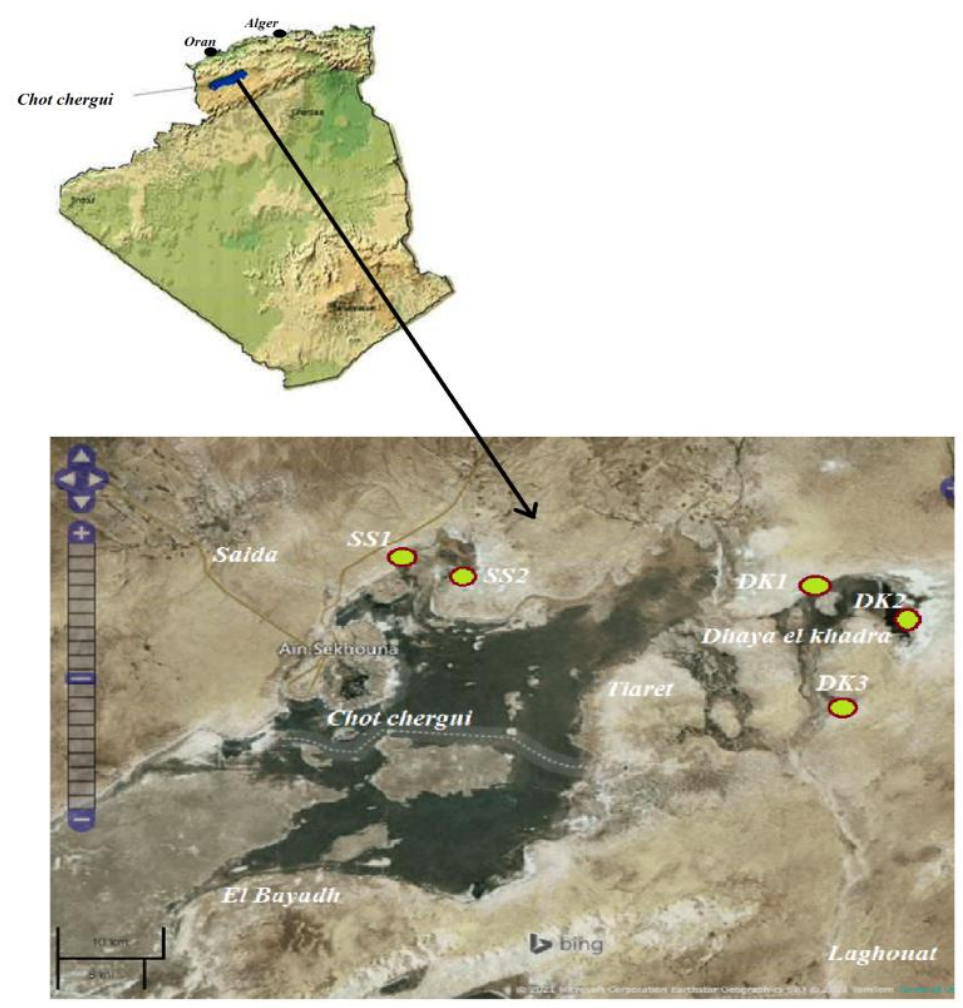

Figure. 1. Geographic location of the studied sites at ChottChergui.

Table. 1. Geographic locationsof studied sites

\begin{tabular}{|c|c|c|c|}
\hline Station & Latitude & Longitude & Altitude (m) \\
\hline DK2 & $34^{\circ} 32^{\prime} 41.16^{\prime \prime} \mathrm{N}$ & $1^{\circ} 20^{\prime} 30.43^{\prime \prime} \mathrm{E}$ & 999 \\
\hline DK1 & $34^{\circ} 34^{\prime} 14.55^{\prime \prime} \mathrm{N}$ & $1^{\circ} 15^{\prime} 54.32$ '” & 1009 \\
\hline DK3 & $33^{\circ} 30^{\prime} 48.40^{\prime \prime} \mathrm{N}$ & 1¹9'29.74"E & 996 \\
\hline SS2 & $34^{\circ} 34^{\prime} 15.16^{\prime \prime} \mathrm{N}$ & $0^{\circ} 56^{\prime} 51.46^{\prime \prime} \mathrm{E}$ & 900 \\
\hline SS1 & $34^{\circ} 33^{\prime} 10.44^{\prime \prime} \mathrm{N}$ & $0^{\circ} 52^{\prime} 15.47{ }^{\prime} \mathrm{E}$ & 998 \\
\hline
\end{tabular}

For the study, 60 samples were carried out at 5 sites (Figure. 1, Table. 1) chosen subjectively (Gounot, 1959) according to the environmental conditions (season, accessibility, as well as the presence of the natural submerged support at the level of the site). 
These are the following stations:

DaitKhadra region (stations DK1,DK2 and DK3): is situated in the eastern ChottChergui, 20 $\mathrm{km}$ in the southwest of the town of Chehaima. It covers an area of 10000 ha. It contains swamps and Sebkha where the water level is about $50 \mathrm{~cm}$ on the shores and $180 \mathrm{~cm}$ in the middle. The water is clear, brackish (saline of: $700-1100 \mathrm{mg} / \mathrm{l}$ )and used for livestock. The vegetation mainly consists of halophyte plants such as: Salsolatetrandra, S. vermiculata, Traganumnudatum, Thymeleamicrophylla, Erodiumglaucophyllum, Typhaanguistifolia, Suedafrucutosa, Tamarixafricana, Atriplexhalimus and Phragmites sp.

Saouss region (stations SS1 and SS2): this area is part of the large eco-complex of ChottChergui. They are part of the large basin of the Oran highlands, which occupies the eastern wetland of the Chott, near the town of Sidi Abed El Rahmane. The water is soft to brackish and permanent. Its level is generally low with an average depth of 0.5 to $1.5 \mathrm{~m}$. The vegetation is also mainly dominated by halophyte plants like that of DaitKhadra.

\section{Sample}

Sampling was carried out during two seasons for each of the stations studied (fall and spring). The samples had stones and pebbles covered on the upper face with a brownish biofilm characterizing the presence of diatoms. The depth of the samples taken varied between 20 and $40 \mathrm{~cm}$ in depth depending on the turbidity and the water level.

Regarding the water physicochemical parameters at the sampled sites, some of them were measured in situ (temperature, $\mathrm{pH}$, conductivity and turbidity) using a Multi-parameter Water Quality Analyzer (Multimeter MM $40+$, Crison Instruments, Spain). The other parameters: dissolved $\mathrm{O}_{2}$, organic matter $(\mathrm{OM}), \mathrm{NH}_{4}, \mathrm{NO}, \mathrm{Cl}, \mathrm{PO}_{4}, \mathrm{Ca}, \mathrm{Mg}, \mathrm{NO}_{3}, \mathrm{SO}_{4}$, Chemical Oxygen Demand (COD), Biochemical Oxygen Demand (BOD) were measured in the Research Laboratory of Soil and Water, Faculty of Nature and Life Sciences, the University of Tiaret, Algeria.

The measurement of dissolved oxygen was carried out using an electrochemical method by an oximeter (HI 2400- Hanna). The chemical oxygen demand (COD) was measured following a chemical oxidation reaction of the reducing materials contained in the water by excess of potassium dichromate (K2Cr2O7) in a medium acidified by sulfuric acid (H2SO4), in the presence of silver sulfate $(\mathrm{Ag} 2 \mathrm{SO} 4)$ and Mercury sulfate $(\mathrm{HgSO} 4)$ whose oxidation is done under boiling for 2 hours (Bartram and Richard, 1996). The determination of the COD concentrations was carried out by aHI-83099 Multi-Parameter Colorimeter instrument (Bountoux, 1993).

According to Rodier (2005), the determination of phosphates in water was based on the formation, in an acidic medium, of a complex with ammonium molybdate and double antimony potassium tartrate; the addition of ascorbic acid makes it possible to reduce the fixing of phosphate ions by giving a complex colored blue which has two maximum absorption values, one at around $700 \mathrm{~nm}$, the other greater at $880 \mathrm{~nm}$.

The determination of chlorides (Cl-), nitrates (NO3-) and nitrites (NO2-) was carried out according to (Rodier, 1996). The organic matter determination was carried out according to Rodier (1996). The analysis procedure was based on an assay using potassium permanganate in a hot alkaline medium.

\section{Identification}

Epilithic diatoms cover the upper surface of substrates with a brownish biofilm characteristic of their high abundance. So, the brushing procedure concerned the upper surface of substrates (natural submerged support) using a Toothbrush. After brushing and rinsing the samples with distilled water, the biofilm was harvested and then a few drops of Lugol solution (Lugol alkaline solution) were added to preserve the epilithic cells in preparation for their study. For the observation of frustules under the microscope, we removed the organic matter from frustulesby adding three volumes of hydrogen peroxide $\left(\mathrm{H}_{2} \mathrm{O}_{2}\right)$ at $30 \%$, for 15 to 20 minutes 
then we added a few drops of $35 \% \mathrm{HCl}$ to the samples to the diatoms in centrifuge tubes. When the preparations have been diluted by a process, we repeated the process at least three times to remove all traces of oxidant. Finally, the diatoms were dried and fixed on a slide with balsam of Canada $(\mathrm{RI}=1.55)$ for their enumeration and identification. Observations of diatom valves was performed at x 1000 magnification using a light microscope (Optika DM15, Italy), and photographs were taken (Roper Scientific Photometrics, COOL SNAPTM). In order to observe diatoms randomly and to avoid counting the same specimen twice, the sample was scanned according to a defined slat (PrygielandCoste, 1993).

For this study, we used the following literature: Baudrimont (1974), Krammer and Langebertalotl (1988), Krammer and Lange-Bertalot (1991a), Krammer and Lange-Bertalot (1991b), Keith et al. (2000), Prygiel and Coste (2000), Taylor et al., (2007), Lavoie et al., (2008), Al-Kandari (2009), Al Yamani and Saburova (2019).

\section{Data analyses}

\section{Diversity indices}

\section{Shannon-Weaver Index (Shannon and Weaver, 1949)}

This index makes it possible to quantify the biodiversity of a study environment and observe an evolution over time: $H^{\prime}=-\sum \mathrm{si}=1 \mathrm{p}_{\mathrm{i}} \log _{2} \mathrm{pi}$, where $\mathrm{H}^{\prime}$ : Shannon-Weaver biodiversity index; $i$ : a species of the studied environment; $p_{i}$ : proportion of a species $i$ in relation to the total number of species in the environment; s: number of species.

The Shannon index is often accompanied by the Piélou Equity index (1966), which represents the ratio of $\mathrm{H}$ 'to the theoretical maximum index in the stand, i.e. in a stand where all the species would have the same number: (Hmax) $\mathrm{E}=\mathrm{H}$ '/ H' max

\section{Canonical Correlation Analysis (ACC)}

Canonical analysis (CA) is a factorial dimension reduction method for the statistical exploration of two sets of quantitative data observed on the same individuals. Canonical analysis (CA) is a method of multidimensional descriptive statistics that has analogies both with principal component analysis (PCA) for the construction and interpretation of graphs, and with linear regression. Statistical analyses were carried out using Pastversion 3 software (Hammer et al., 2001).

\section{Results and discussion}

\section{Floristic diversity}

The results obtained allowed us to identify 36 taxa of diatoms in the ChottChergui region (Table. 2). These taxa belong to 21 different genera and 13 botanical families. The majority of the taxa identified are known to be cosmopolitan as it was been verified by Baudrimont (1974). In fact, most of our species were recorded by this authors in his study on the diatoms of arid and semi-arid areas of Algeria. We also found that the majority of our taxa were also recorded by some authors in North Algeria (Petit, 1895; Al-Asadi et al., 2006; Chaib et al., 2011; Chaib and Tison-Rosebery, 2012; Nehar et al, 2014; Nehar, 2016).

The number of 36 taxa obtained is considered interesting compared to the other rare studies published in Algeria, in particular that of El Haouati et al (2015) in the Lake of Reghaya near Algiers which counted 24 taxa, but also the study of Nehar and al (2014) in the two sites of El-Hammam stream at Mascara and the estuary of Cheliff river at Mostaganem with a total of 56 taxa.

Other studies such as that of Chaib et al (2014) report a greater number of identified taxa. These authors report 322 taxa for El wed el Kebir in the northeast of the country. However, the literature review conducted by Nehar (2016) on all the recorded Algerian taxa, reported 359 taxa for the whole country; so, this number is to be verified. 
Other studies in Morocco also report significant numbers of Diatom taxa identified, in particular Jaghror et al. (2017) in the Sibouwadi with 226 taxa.

Regarding the dominant families, it is the Naviculaceae which predominate (25.71\%), followed by the Surirellaceae (22.86\%) and the Bacillariaceae (17.14\%, Figure. 2).

Table 2. The diatom taxa identified in the study area

\begin{tabular}{|c|c|c|c|c|c|c|c|c|c|c|c|c|}
\hline & \multicolumn{5}{|c|}{ Spring } & \multicolumn{5}{|l|}{ Fall } \\
\hline & & & SS1 & SS2 & $D K 1$ & $D K 2$ & $D K 3$ & SS1 & SS2 & $D K 1$ & $D K 2$ & $D K 3$ \\
\hline Family & Taxa & Code & + & + & + & + & + & + & + & + & + & + \\
\hline Achnanthidiaceae & $\begin{array}{l}\text { Achnanthidiumexiguum(Grunow) Czarnecki } \\
(=\text { Achnanthesexiguarunow in Cleve et } \\
\text { Grunow 1880) }\end{array}$ & AEXI & - & - & + & + & + & - & + & + & - & - \\
\hline Amphipleuraceae & $\begin{array}{l}\text { Halamphora coffeaeformis (Agardh) } \\
\text { Levkov }\end{array}$ & $\mathrm{HCOF}$ & + & + & + & - & + & - & - & + & + & - \\
\hline \multirow{6}{*}{ Bacillariaceae } & NitzschiacommunisRabenhorst & NCOM & - & - & + & - & + & + & + & - & - & - \\
\hline & NitzschiadraveillensisCoste et Ricard & NDRA & + & + & - & + & - & - & - & - & - & - \\
\hline & NitzschiahantzschianaRabenhorst & NHAN & - & + & + & + & - & - & - & - & - & - \\
\hline & Nitzschialinearisvar. subtilis GrunowHustedt & NLIN & + & + & + & + & + & + & + & + & + & + \\
\hline & Nitzschiapalea (Kützing) W. Smith & NPAL & + & + & + & + & + & - & - & + & + & - \\
\hline & $\begin{array}{l}\text { Tryblionellahungarica (Grunow) DG Mann } \\
\text { (=Nitzschiahungarica Grunow) }\end{array}$ & THUN & - & - & - & - & - & + & + & + & - & + \\
\hline Catenulaceae & Amphora pediculus(Kützing) Grunow & APED & + & - & - & + & - & - & - & - & - & - \\
\hline Centrophycidées & Coscinodiscus marginatus Ehrenberg & CMAR & - & - & - & - & - & - & + & + & + & + \\
\hline \multirow{2}{*}{ Cocconeidaceae } & Campylodiscus clypeus Ehrenberg & CCLY & + & + & + & + & + & + & + & + & + & + \\
\hline & Cocconeispediculus Ehrenberg & CPED & + & - & - & - & + & - & - & - & - & - \\
\hline \multirow[t]{2}{*}{ Cymbellaceae } & $\begin{array}{ll}\text { EncyonemaminutumHilse } & \mathrm{ex} \\
\text { Rabenhorst }(=\text { CymbellaminutaHilse } & \mathrm{ex} \\
\text { Rabenhorst } 1862) & \\
\end{array}$ & EMIN & - & + & + & - & - & - & - & - & - & - \\
\hline & $\begin{array}{l}\begin{array}{l}\text { Encyonemasilesiacum }(\text { Bleisch}) \\
(=\text { CymbellasilesiacaBleisch) }\end{array} \\
\text { D DG }\end{array}$ & ESIL & + & + & + & - & - & - & - & - & - & - \\
\hline Fragilariaceae & $\begin{array}{l}\text { Ulnaria ulna (Kützing) Compère (=Fragilaria } \\
\text { ulna (Nitzsch) Lange-Bertalot } 1980)\end{array}$ & UULN & + & - & + & + & + & - & - & + & + & + \\
\hline Mastogloiaceae & MastogloiabrauniiGrunow & MBRA & + & + & + & + & + & + & + & + & + & + \\
\hline \multirow{9}{*}{ Naviculaceae } & Craticulahalophila(Grunow) DG Mann & CHAL & + & + & + & + & + & - & + & + & - & + \\
\hline & Gyrosigmaacuminatum (Kützing) Rabenhorst & GACU & + & + & + & + & - & - & + & - & - & - \\
\hline & $\begin{array}{l}\text { Navicula reidianaBrébisson }(=\text { Navicula } \\
\text { tenellanBrébisson ex Kützing 1849) }\end{array}$ & NRAD & - & - & + & + & + & - & - & - & - & - \\
\hline & NaviculacryptocephalaKützing & NCRP & + & + & - & - & - & + & + & + & + & + \\
\hline & NaviculacryptotenellaLange-Bertalot & NCRT & - & - & + & + & - & - & - & + & + & - \\
\hline & Navículagottlandica Grunow & NGOT & - & - & + & + & + & - & - & - & + & + \\
\hline & $\begin{array}{l}\text { NaviculagregariaDonkin } \\
(=\text { NaviculagregalisCholnoky) }\end{array}$ & NGRE & - & - & - & + & + & - & - & - & - & - \\
\hline & Navicularostellata Kützing & NROS & + & + & - & + & - & - & - & - & + & + \\
\hline & $\begin{array}{l}\begin{array}{l}\text { Navicymbulapusilla }(\text { Grunow }) \\
\text { (=Cymbellapusilla } \text { Grunow })\end{array} \quad \text { Krammer } \\
\end{array}$ & NPUS & + & + & + & + & + & + & + & + & + & + \\
\hline Pleurosigmataceae & Pleurosigmasalinarum Grunow & PSAL & + & + & + & + & + & + & + & + & + & + \\
\hline \multirow{2}{*}{ Stephanodiscaceae } & CyclotellameneghinianaKützing & CMEN & - & - & - & - & - & + & + & - & + & - \\
\hline & Cyclotellastelligera Cleve et Grunow & CSTE & + & + & - & - & - & - & - & - & - & - \\
\hline \multirow{7}{*}{ Surirellaceae } & Cymatopleurasolea Brébisson & CSOL & + & + & + & - & + & + & + & - & - & - \\
\hline & $\begin{array}{l}\text { Cymatopleurasoleavar.apiculata }(\mathrm{W} \text {. Smith) } \\
\text { Ralfs }\end{array}$ & CSAP & - & - & + & + & - & - & - & - & - & - \\
\hline & 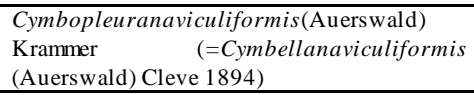 & CNAV & - & - & - & - & - & - & + & + & - & - \\
\hline & Stenopterobiacurvula (W. Smith) Krammer & SCRU & + & + & + & + & + & + & + & + & + & - \\
\hline & $\begin{array}{l}\text { Surirellabrebissoniivar. } \\
\text { brebissoniiKrammer\& Lange-Bert. }\end{array}$ & SBRE & + & + & - & + & + & - & - & + & - & + \\
\hline & SurirellacrumenaBrébisson ex Kützing & SCRU & - & - & - & - & - & + & + & - & + & + \\
\hline & Surirellaovalis Brébisson & SOVA & + & - & + & + & - & - & + & + & - & - \\
\hline Thalassiosiraceae & Thalassiosirapseudonana Hasle\&Heimdal & TPSE & & - & + & + & 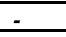 & - & - & & & \\
\hline
\end{tabular}

Chaib et al (2011) in their study in wadi el Kebir reported also the dominance of Naviculaceae. Otherwise, Surirellaceae and Bacillariaceae do not usually dominate this type of inventory according to the consulted literature.

\section{The most dominant species}

Figure 3 shows the distribution of species across the explored stations. It is found that the diatoms flora of Chott Chergui is mainly dominated by 3 species (Mastogloiabraunii, Navicymbulapusilla and Campylodiscus clypeus). 
Mastogloiabraunii present the highest percentages of abundance recorded in spring DK3 (26.6\%), SS1 (25\%), DK2 (22.31\%) and SS2 (21.5\%). In this last station, the species presents a high rate also in fall with $28.53 \%$.

The second species (Navicymbulapusilla) was also found in abundance, but shows much more dominance in the fall with $40.29 \%, 38.07 \%$ and $26.88 \%$ at sites DK2, SS1 and DK3 respectively.

The third taxa (Campylodiscusclypeus) is a typical species of dirty water, widespread in this area with a dominance of (A> 20) during spring DK1 (35.83\%), DK2 (20.67\%) and DK3 $(31.41 \%)$.

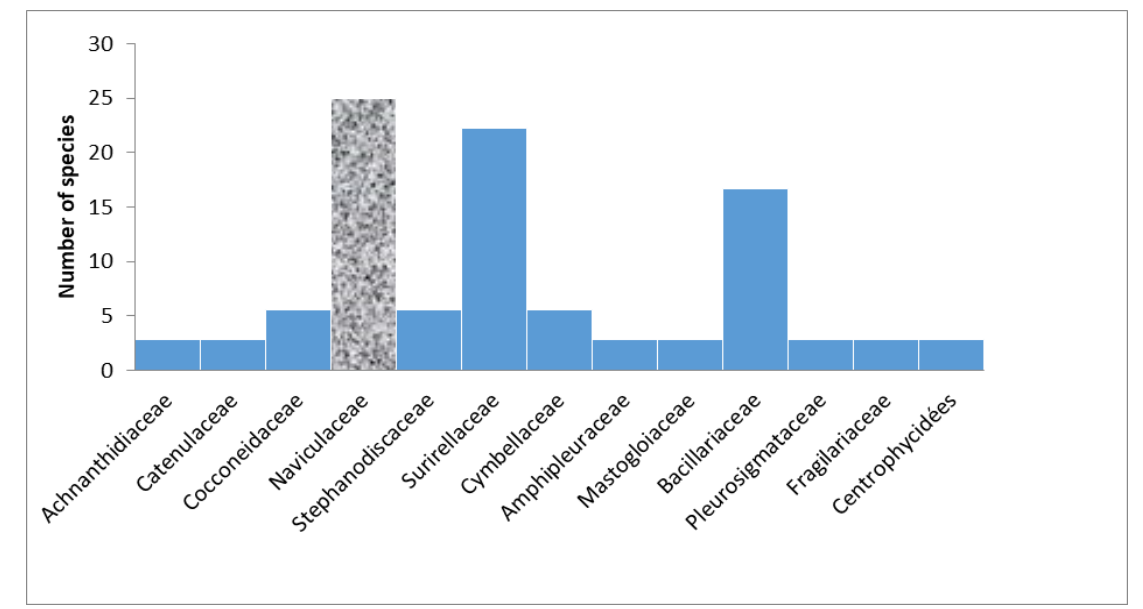

Figure 2. The most dominant families (number of species-

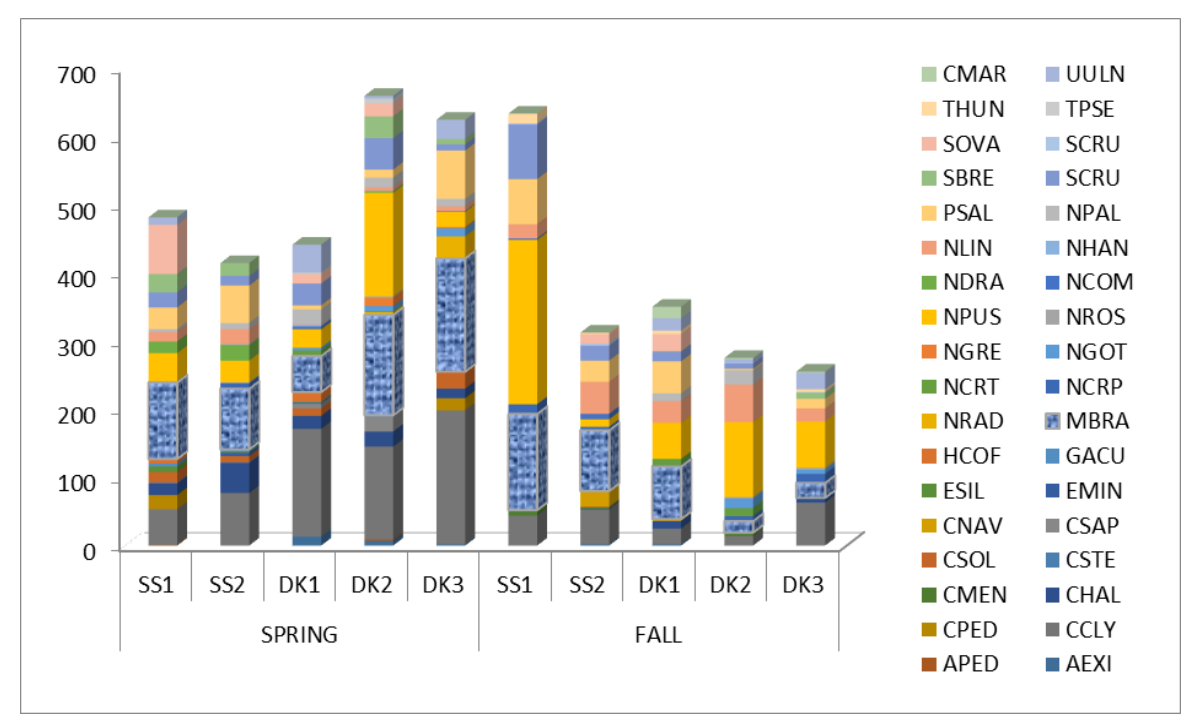

Figure. 3. Distribution and abundance of species across the studied sites during the spring and fall season

\section{Diversity indices}

In general, the obtained results show that the specific diversity in the fall season is greater than spring. On the other hand, during spring, there are more individuals (Table.3). This can be explained by the fluctuations of some physico-chemical parameters of the water in relation to the seasons. Indeed, parameters such as $\mathrm{pH}$ and salinity changes depending on the season (Farhadian et al. 2015). This is also the case for other parameters (topography, fluctuations in fresh water, tides, discharges and evaporation), which are environmental factors in constant variation according to the seasons (Gastineau, 2012). 
Table. 3. Diversity and equity indices (number of taxa and individuals)

\begin{tabular}{lllllllll}
\hline & \multicolumn{2}{l}{ Taxa (Number) } & \multicolumn{2}{l}{ Individuals(Number) } & \multicolumn{2}{l}{ Shannon I } & \multicolumn{2}{l}{ Equity_I } \\
\cline { 2 - 9 } Season & F & S & F & S & F & S & F & S \\
SS1 & 21 & 12 & 195 & 562 & 4,33 & 4,12 & 0,74 & 0,72 \\
SS2 & 19 & 17 & 310 & 416 & 3,71 & 3.98 & 0,75 & 0,66 \\
DK1 & 23 & 17 & 281 & 599 & 4.27 & 3,76 & 0,62 & 0,55 \\
DK2 & 23 & 15 & 252 & 663 & 3,95 & 3,75 & 0,77 & 0,78 \\
DK3 & 18 & 13 & 391 & 416 & 2,01 & 3.89 & 0,69 & 0,63 \\
\hline
\end{tabular}

The obtained values from Shannon index confirm that the specific diversity observed during fall in the sampled stations is greater than that observed during the spring. The same results were observed by Farhadian et al., 2015 in Iran. Moreover, some equitability between the stations is quite easily observable, especially between the two seasons.

\section{Ecology of diatoms and water quality in Chott Chergui}

According to the classification of Van Dam et al. (1994), the chlorine values between 240 and $939 \mathrm{mg} / \mathrm{l}$ reflect the dominance of the medium brackish class. From the physico-chemical analyses results (Table. 4), the measured temperatures varies from one site to another. This makes it possible to classify the diatoms of Chott Chergui in 02 classes: the Euthermesdiatoms which characterize the region of Saouss and Ain Teddese; and the Mesotherms observed especially in DaitKhadra. While based on the $\mathrm{pH}$, it appears that the diatoms encountered are alkaphilic across the majority of sites. On the other hand, the physico-chemical results lead us to conclude that the mineralization is strong in the five studied stations. Indeed, these waters are characterized by the predominance of $\mathrm{SO}_{4}$ sulphates (255.1-511.6 mg/l), sodium $\mathrm{Na}^{+}(38-343 \mathrm{mg} / \mathrm{l})$, while the very high levels of magnesium exceeding $200 \mathrm{mg} / \mathrm{l}$ seems to be due to the drainage of sewage from the nearest commune of Sidi Abed El Rahmen.

Otherwise, in DaitKhadra (DK2, DK3), we observed high concentrations of nitrite and phosphate during the spring. This is due to the agricultural activities (fertilizer and sheep breeding) practiced in the Chehaima region near these stations.

In general, it appears that in ChottChergui, the concentrations of the physicochemical parameters of water, do not change during the two periods (fall and spring) which could be explained, firstly by the lack of precipitation, and then by the high temperatures characterizing the region during the two studied periods.

Table. 4. Water physico-chemical characteristics in the study area.

\begin{tabular}{|c|c|c|c|c|c|c|c|c|c|c|c|c|c|c|c|c|c|}
\hline Site & Season & $\begin{array}{l}T \\
\end{array}$ & $p H$ & $C E$ & $\begin{array}{l}\text { Tu } \\
r\end{array}$ & $\mathrm{O}_{2}$ & $O M$ & $\begin{array}{l}\mathrm{NH} \\
4\end{array}$ & $\mathrm{NO}$ & $\mathrm{Cl}$ & $\begin{array}{l}P O \\
3\end{array}$ & $\mathrm{Ca}$ & $M g$ & $\mathrm{NO}_{3}$ & $\mathrm{SO}_{4}$ & $\begin{array}{l}C O \\
D\end{array}$ & $\begin{array}{l}B O \\
D\end{array}$ \\
\hline $\begin{array}{l}S S \\
1\end{array}$ & & 37,9 & 8,4 & $\begin{array}{l}5798, \\
4\end{array}$ & 15 & 40,2 & 27,2 & $\begin{array}{l}0,0 \\
9\end{array}$ & $\begin{array}{l}0,15 \\
4\end{array}$ & 939 & $\begin{array}{l}0,1 \\
3\end{array}$ & 130 & 271 & 39,5 & 448 & 221 & 22,1 \\
\hline $\begin{array}{l}S S \\
2\end{array}$ & Sprin & 32,7 & $\begin{array}{l}7,5 \\
5\end{array}$ & $\begin{array}{l}7354, \\
8\end{array}$ & 12 & 60,7 & 24,3 & $\begin{array}{l}0,0 \\
8\end{array}$ & $\begin{array}{l}0,25 \\
4\end{array}$ & $\begin{array}{l}572,9 \\
9\end{array}$ & $\begin{array}{l}0,1 \\
7\end{array}$ & 343 & 232 & 79,2 & 451 & 86 & 8,6 \\
\hline $\begin{array}{l}D K \\
1\end{array}$ & $g$ & 20,1 & $\begin{array}{l}7,9 \\
8\end{array}$ & $\begin{array}{l}8001, \\
2\end{array}$ & 12 & 52,3 & $\begin{array}{l}26,0 \\
5\end{array}$ & $\begin{array}{l}0,2 \\
6\end{array}$ & 0,18 & $\begin{array}{l}553,2 \\
5\end{array}$ & $\begin{array}{l}0,0 \\
9\end{array}$ & 83 & $\begin{array}{l}198, \\
5\end{array}$ & 170 & $\begin{array}{l}511, \\
6\end{array}$ & 70 & 7 \\
\hline $\begin{array}{l}D K \\
2\end{array}$ & & 17,4 & $\begin{array}{l}8,0 \\
7\end{array}$ & $\begin{array}{l}8007, \\
9\end{array}$ & 13 & $\begin{array}{l}44,1 \\
2\end{array}$ & $\begin{array}{l}32,7 \\
8\end{array}$ & $\begin{array}{l}0,0 \\
9\end{array}$ & $\begin{array}{l}0,32 \\
7\end{array}$ & 240 & $\begin{array}{l}0,0 \\
9\end{array}$ & 98 & 245 & 51 & $\begin{array}{l}357, \\
6\end{array}$ & 77 & 7,7 \\
\hline $\begin{array}{l}D K \\
3\end{array}$ & & 18,9 & $\begin{array}{l}8,1 \\
2\end{array}$ & $\begin{array}{l}7983, \\
7\end{array}$ & 17 & $\begin{array}{l}92,1 \\
2\end{array}$ & 36,4 & $\begin{array}{l}0,1 \\
2\end{array}$ & $\begin{array}{l}0,14 \\
5\end{array}$ & 376 & $\begin{array}{l}0,0 \\
2\end{array}$ & 127 & $\begin{array}{l}188, \\
7\end{array}$ & 66 & $\begin{array}{l}255, \\
1\end{array}$ & 150 & 15 \\
\hline $\begin{array}{l}S S \\
1\end{array}$ & & 30,7 & $\begin{array}{l}9,0 \\
3\end{array}$ & $\begin{array}{l}7765, \\
1\end{array}$ & 19 & $\begin{array}{l}20,1 \\
4\end{array}$ & $\begin{array}{l}47,0 \\
2\end{array}$ & $\begin{array}{l}0,2 \\
1\end{array}$ & $\begin{array}{l}0,23 \\
1\end{array}$ & 412,1 & $\begin{array}{l}0,0 \\
6\end{array}$ & 254 & $\begin{array}{l}197, \\
1\end{array}$ & 110 & 313 & 136 & 13,6 \\
\hline $\begin{array}{l}S S \\
2\end{array}$ & Fall & 31,5 & $\begin{array}{l}9,6 \\
5\end{array}$ & $\begin{array}{l}7549 \\
2\end{array}$ & 12 & 27,6 & 41,1 & $\begin{array}{l}0,0 \\
5\end{array}$ & $\begin{array}{l}0,14 \\
3\end{array}$ & 330,2 & $\begin{array}{l}0,1 \\
2\end{array}$ & $\begin{array}{l}143, \\
4\end{array}$ & 154 & 87,5 & 296 & 79 & 7,9 \\
\hline $\begin{array}{l}D K \\
1\end{array}$ & & 12,3 & $\begin{array}{l}9,3 \\
2\end{array}$ & $\begin{array}{l}8320, \\
2\end{array}$ & 16 & 49,2 & 30,2 & 1,2 & $\begin{array}{l}0,12 \\
1\end{array}$ & 693,5 & $\begin{array}{l}0,2 \\
4\end{array}$ & 88 & $\begin{array}{l}196, \\
5\end{array}$ & 99,1 & 420 & 201 & 20,1 \\
\hline $\begin{array}{l}D K \\
2\end{array}$ & & 12,1 & $\begin{array}{l}8,4 \\
1\end{array}$ & $\begin{array}{l}5753, \\
6\end{array}$ & 14 & $\begin{array}{l}36,0 \\
6\end{array}$ & 20,3 & $\begin{array}{l}0,0 \\
5\end{array}$ & $\begin{array}{l}0,78 \\
8\end{array}$ & 698,1 & $\begin{array}{l}0,3 \\
1\end{array}$ & 92,4 & $\begin{array}{l}242, \\
8\end{array}$ & $\begin{array}{l}135, \\
7\end{array}$ & 435 & 178 & 17,8 \\
\hline $\begin{array}{l}D K \\
3\end{array}$ & & 15,7 & $\begin{array}{l}9,3 \\
3\end{array}$ & $\begin{array}{l}6036, \\
7\end{array}$ & 13 & 54,6 & 30,7 & $\begin{array}{l}0,0 \\
9\end{array}$ & $\begin{array}{l}0,12 \\
9\end{array}$ & 563,4 & 0,9 & $\begin{array}{l}162, \\
5\end{array}$ & $\begin{array}{l}244, \\
2\end{array}$ & 78,2 & 468 & 169 & 16,9 \\
\hline
\end{tabular}

Regarding the attraction of the diatomic community to saprobic conditions, we report the predominance of the $\alpha$-mesosaprobicclass during fall and spring (Figure. 4, 5). This has been observed in several studies focusing on water quality (Chaib and Tison-Roserbery, 2012; Neharet al 2015; Nehar, 2016). This is also the case concerning the dominance of 
Navicymbulapusilla, known by its ecology, preferring oligotrophic waters with a moderate to high content of mineral salts, in particular waters with high concentrations of $\mathrm{Ca}^{+}$and $\mathrm{Cl}$.

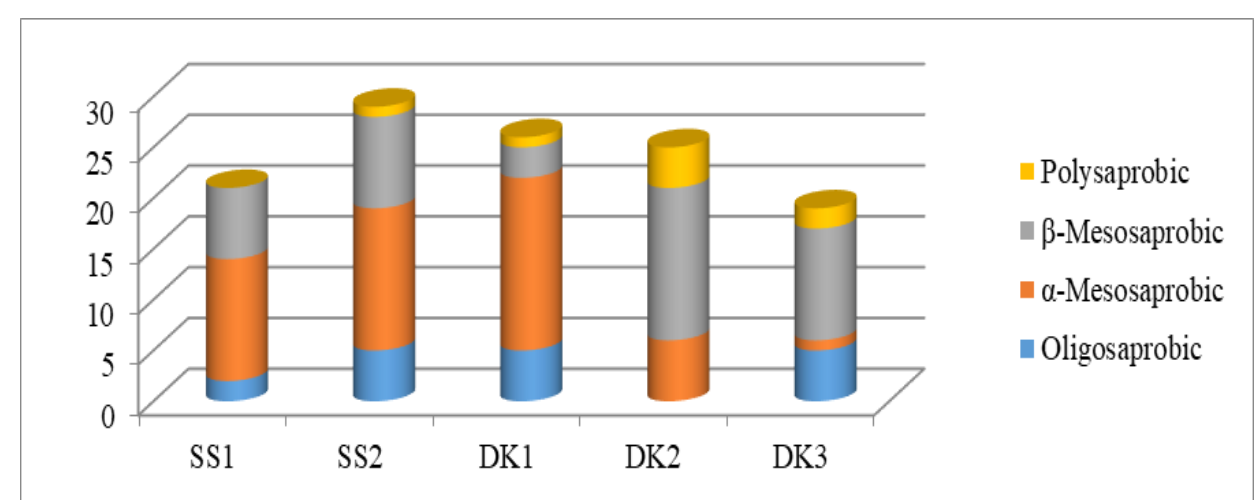

Figure. 4. Affinity of the diatoms community to physicochemical parameters (spring).

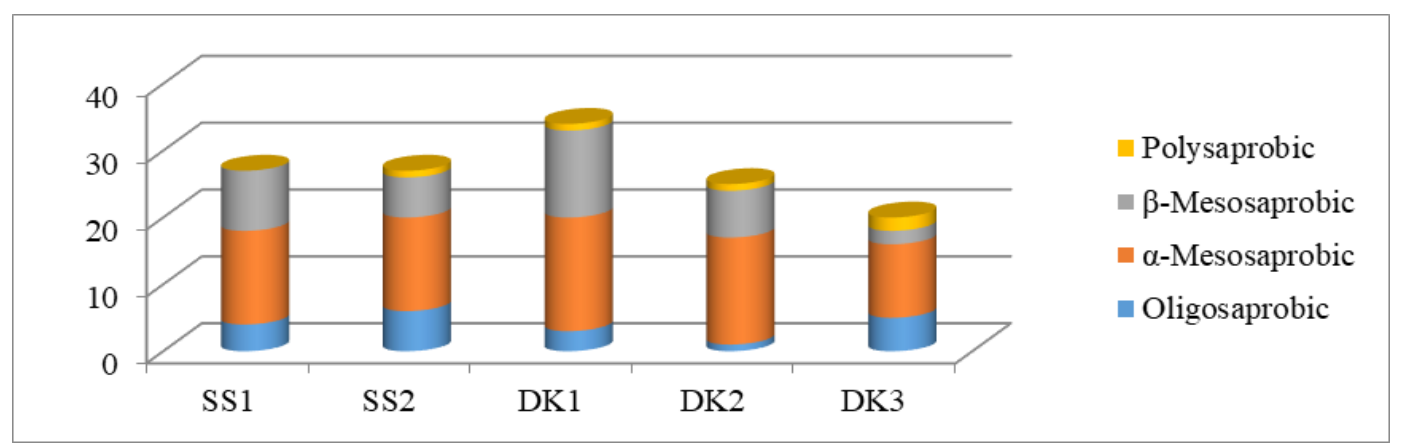

Figure. 5. Affinity of the diatomic community to physico-chemical parameters (fall)

At the DK2 and DK3 sites, we observed the dominance of the class of $\beta$ mesosaprobicdiatoms such as Gomphonemaparvulum and Nitzschiapalea during the spring period. These species have been observed in the agricultural runoff zone (Dait El Khadra) in agreement with the observations of several authors in the USA, Japan, Poland and Germany (Lobo et al., 1995; Leland and Porter, 2000; Köster and Hübener, 2001).

Meso-eutraphentic taxa (Navicymbulapusilla, Campylodiscusclypeus, Cocconeispediculus and A chnanthidiumexiguum) are well adapted to moderate concentrations approaching alkaline waters. Contrastly, the species of Eutraphentic class responds strongly to high nutrient enrichment of the environment, where we notice the dominance of some species such asMastogloiabraunii and Surirellaovalis.

Table. 5. The pollution classes at the study area

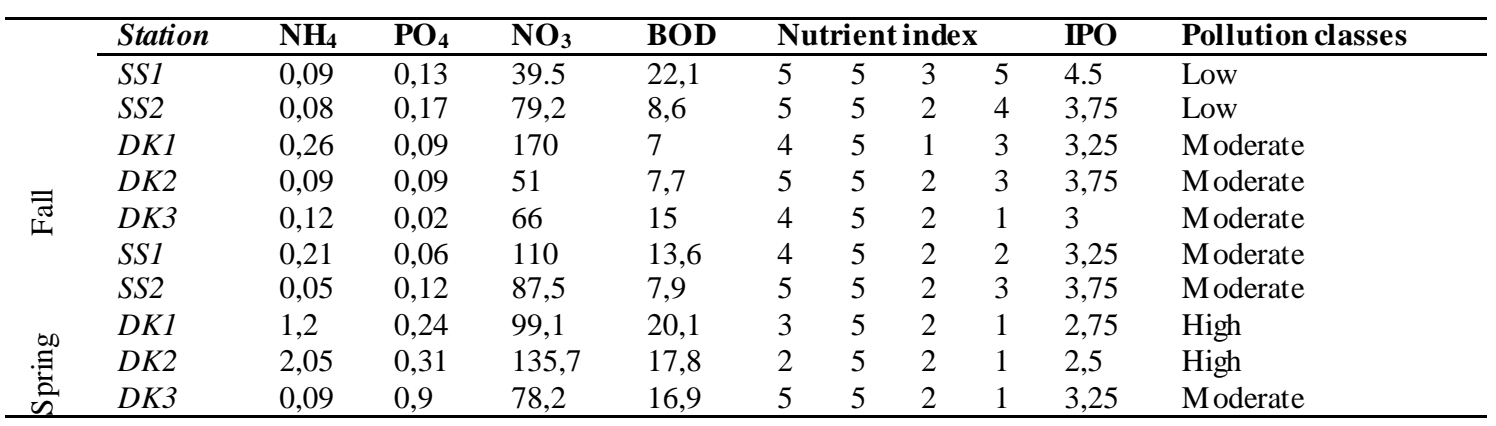

According to the organic matter content and the IPO values (Table. 5), the diatoms indicate the degree of weathering of the waters of the study region. This vulnerability of diatoms with respect to organic pollution highlights three classes according to the pollution degree:

- Strong organic pollution (IPO = 2.5 and 2.75) observed in DaitKhadra in spring, confirming the impact of drainage in these places, where permeability is high. This can 
be explained by the high concentrations of minerals $\left(\mathrm{Na}^{+}, \mathrm{Cl}^{-}\right.$and $\left.\mathrm{SO}_{4}\right)$ linked to urban and agricultural wastewater flowing into these waters.

- Moderate pollution: observed in most of the sites during the two periods with IPO whichvaries between 3 and 3.75, confirming the high rate of saline nutrients.

- Low pollution: Observed in Saouss and Ain Teddese (SS1 and SS2) in the fall, which is explained by the decrease in evaporation following the low temperatures during this period, the low concentration of nutrients in the environment, but also the remoteness of sites from urban areas.

\section{Parameters influencing the distribution of diatoms.}

The growth and distribution of algae would be mainly controlled by temperature, light, nutrient concentration, movement of water masses or even salinity (Bussard, 2015).

From the canonical analysis (Figure.6), we can distinguish the Axis 1, which is positively correlated with temperature, separating species from moderately polluted SS1 sites in fall. Temperature is the variable that seems to be more related to the distribution of Surirellaovalis, Nitzschiadraveillensis, Cyclotellastelligera and Encyonemasilesiacum.

The second important variable among the Axis 1 is the concentrations of dissolved $\mathrm{O}_{2}$, which includes moderately polluted sites DK1 and DK3, with the presence of two species (Naviculareidiana and Halamphoracoffeaeformis) characterizing this type of biotope (Triest et al., 2001). In addition, the presence of Amphora pediculus, Craticulahalophila and Campylodiscus clypeus is positively correlated with conductivity.

Other species such as Mastogloiabraunii (most abundant in the 5 sites), Pleurosigmasalinarum and Nitzschiacommunis present affinity for $\mathrm{Cl}^{-}$and $\mathrm{Ca}^{+}$ions and cations refer to salinity. These species are known by their affinities to biotopes with high saline concentrations, as reported by Leland and Porter (2000). It was shown that the increase in salinity would therefore cause a change in the specific composition within the periphyton, and result in the disappearance of some species most sensitive to this parameter. These species will be replaced by others that are more tolerant, as several studies show (Busse et al., 1999; Ziemann et al., 2001).

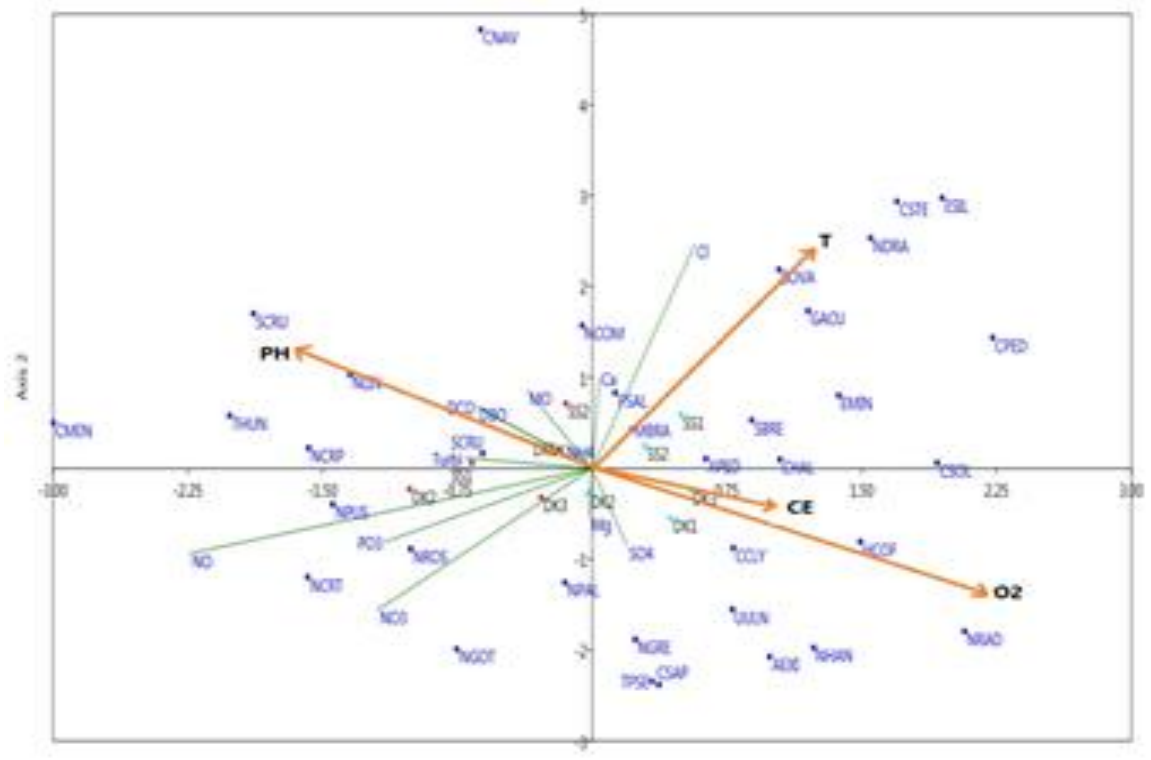

Figure.6. Canonical correlation analysis of diatoms taxa in the study area. The orientation of each of the main variable in relation to each of these axes is presented by an arrow, the length of which indicates the degree of correlation with those axes 
On the other side of the Axis 1, Navicymbulapusilla, Naviculacryptotenella and Navicularostellataare positively correlated with $\mathrm{NO}_{2}{ }^{-} \mathrm{PO}_{3}$ and $\mathrm{NO}_{3}{ }^{-}$. These species are indeed observed in the agricultural runoff areas of DaitKhadra in spring. They are present in water with high mineralization at high concentrations of nitrate and phosphates, as shown by the work of Chaib and Tison-Roserbery (2012), Lobo et al. (2015), Nehar et al (2016) and Rimet (2017, 2018).

The arrangement of the stations on the factorial plane confirms the difference between the stations of Dait El Khadra and those of Saous mainly in terms of water temperature and conductivity. This imposes a different distribution of species between the two regions despite some differences in the specific composition between the two seasons studied.

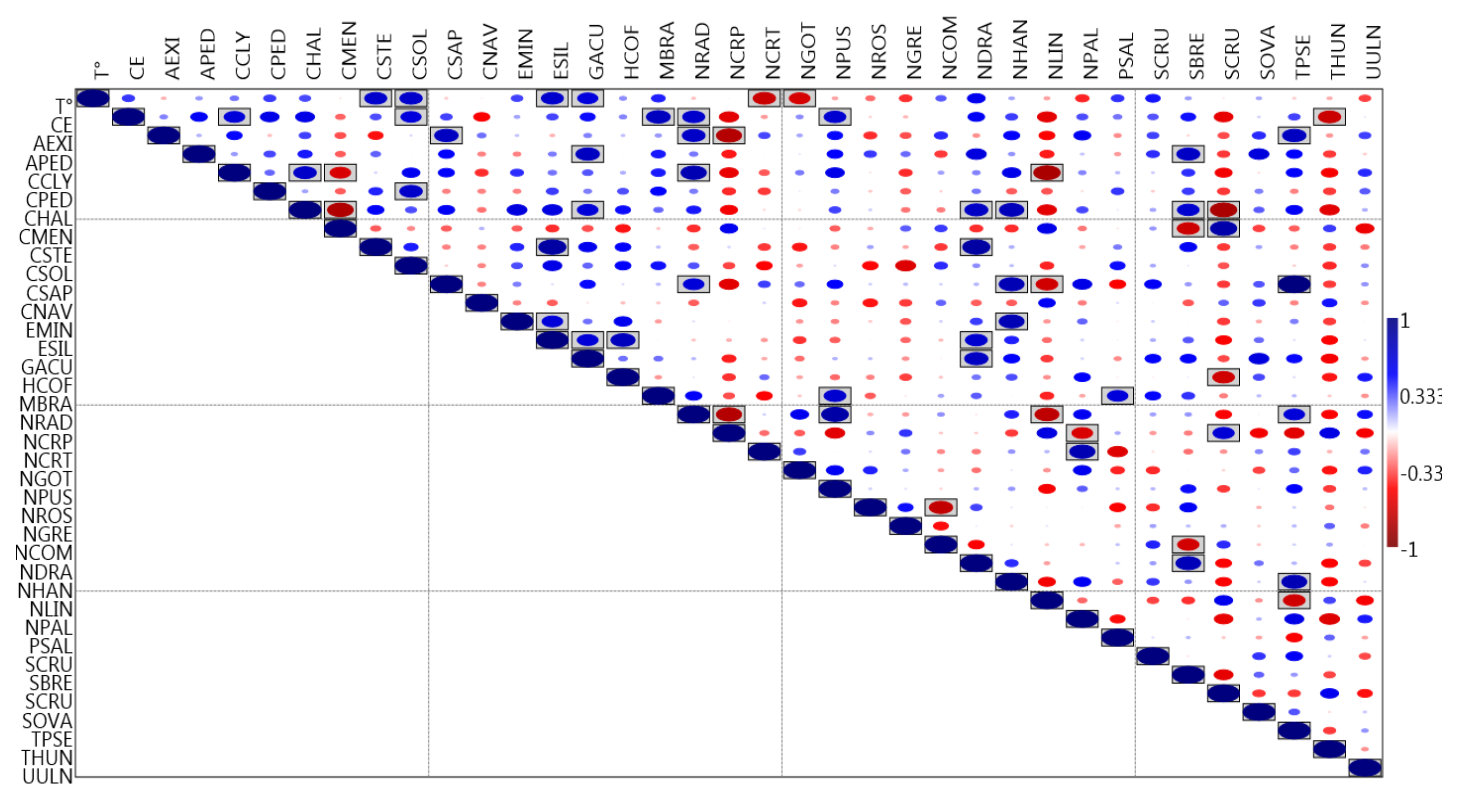

Figure 7. Spearman's correlation between conductivity, temperature and the diatom taxa

Being the main parameters visibly influencing the distribution of diatoms in the study area, Spearmen correlation between these main important parameters (temperature and conductivity) and most abundant diatom taxa such as Navicymbulapusilla, Mastogloiabraunii, Naviculareidiana, Campylodiscusclypeusis shown in the figure 7. Spearman correlation coefficient is positive and Tryblionella Hungarica correlated negatively with conductivity. On the other part of the plot, we notice Cymatopleurasolea, Cyclotellastelligera, Encyonemasilesiacum and Gyrosigmaacuminatum wich are correlated positively with the temperature, while other species such as Naviculacryptotenella and Navículagottlandica are negatively correlated with this same parameter. In general, Spearman correlation plot confirms that the distribution of the main diatom species in the ChottChergui region is mainly controlled by these two parameters. Any instability or variation of these parameters could contribute to the modification of the specific composition of these stations (Nehar, 2016). In the current context of climate change, the stability of these fragile ecosystems must constitute a priority for organizations responsible for environmental protection.

\section{Conclusion}

The results obtained introduce more understanding of the diatom flora in Algeria, where there remains a paucity in the research. This study identifies the diversity in diatom taxa, which has been highlighted in the ChottChergui region, namely 36 taxa belonging to 13 families. Our study found that the distribution of diatom taxa is mainly controlled by temperature and conductivity, which is reflected in the difference in specific composition and number of individuals observed between the two observation periods (fall and spring). 


\section{Références}

Ait Hammou M 2015. Analyse taxonomique et écologique des lichens de la région de Tiaret. ThèseDoct, Univ. Oran. 350p.

Al Asadi MS. Randerson P. Benson Evans K 2006. Phytoplankton population dynamics in three West Algerian rivers: The River Cheliff and its tributary, River Mina. Marina Mesopotamica, vol.1(1), 48-72.

Al Kandari M. Al Yamani FY. Al Rifaie K 2009. Marine Phytoplankton Atlas of Kuwait's Waters. Kuwait Institute for Scientific Research. 338p.

Al Yamani FY. Saburova MA 2019. Marine phytoplankton of Kuwait's waters. Cyanobacteria, Dinoflagellates, Flagellates.Kuwait Institute for Scientific Research. Vol.1. 469p.

Al Yamani FY. Saburova MA 2019. Marine phytoplankton of Kuwait's waters Diatoms. Kuwait Institute for Scientific Research. Vol. 2.338p.

Battarbee RW. Charles D. F., Christian B., Cumming B.F. \&Ingemar R., 2010. Diatoms as indicators of surface-water acidity. In: The diatoms: Applications for the environmental and earth sciences. Cambridge UniversityPress. 667p.

Baudrimont $R$ 1970. Contribution à l'étude de la flore algologique de l'Algérie. I. Hydrobiologie du Chott Ech Chergui. Bull. Soc. Hist. Nat. Afr. Nord. 61: 155-167.

Baudrimont R 1974. Recherches sur les Diatomées des eaux continentales de l'Algérie.Ecologie et paléo-écologie. Mémoire, Soc. Hist. Nat. Afr. Nord, nouvelle série $12: 265$.

Bussard A 2015. Capacités d'acclimatation des diatomées aux contraintes environnementales. ThèseDoct. Museum National d'histoireNaturelle.Paris. France. 302p.

Busse S. Jahn R. Schulz CJ 1999. Desalinization of running waters: Benthic diatom communities: A comparative field study on responses to decreasing salinities. Limnologica, 29: 465-474.

CFT (Conservation des forêts de Tiaret) 2016. Rapport consulté le 01-06-2020.

Chaïb N. Alfarhan AH. Al Rasheid KAS. Samraoui B 2011. Environmental determinants of diatom assemblages along a North African wadi, the Kebir-East, North east Algeria. Journal of Limnology. 70 (1): 33-40.

Chaïb N. Tison-Rosebery J 2012. Biological diatom index in the Kebir-East wadi, Algeria. African Journal of Aquatic Science. 37 (1): 59-69.

Chaïb N. Tison-Rosebery J 2012. Water quality assessment and application of thebiological diatom index in the Kebir-East wadi, Algeria. African Journal of AquaticScience. 37 (1): 59-69.

El Haouati H. Arab A. Tudesque L. Lek S amraoui B 2015. Study of the Diatoms of Reghaia Lake, Northern Algeria. Revue d'Ecologie. 70 : 1-44.

Farhadian O. Pouladi M. Vazirizadeh A Sedaghat RA. 2015. Study of diatoms seasonal distribution and biodiversity in Helleh River Estuary, Persian Gulf. EnvironmentalStudies of Persian Gulf. 2 (1), 32-44.

Gastineau R 2012. Biodiversité, reproduction et phylogénie des diatomées bleues du genre Haslea et valorisation de leurs pigments de type marennine. ThèseDoct.Univ. du Maine. Le Mans. France. 329p.

Gounot M 1960. Contribution à l'étude des groupements végétaux messisicoles et rudéraux de la Tunisie. Ann. Serv. Bot. Agron. Tunisie, 275p.

Hammer Øyvind Harper David AT. Paul DR 2001. Past: Paleontological Statistics Software Package for Education and Data Analysis. Palaeontologia Electronica, vol. 4, issue 1, art. 4: 9pp.

Jaghror H. Serieyssol K. Beauger A. Loukili K. Fadli M. 2017. Diatom Diversity and Ec ology of the Sebou Watershed (Morocco). Biolife International Quarterly Journal of Biology \& Life Sciences. DOI: 10.17812/blj.2017.5423

Keith EC. Donald FC 2000. Diatoms of low alkalinity lakes in the northeastern united states. Academy of Natural Sciences of Philadelphia Special Publication. Academy of Natural Sciences. $152 \mathrm{p}$.

Köster D. Huebener T 2001. Application of Diatom Indices in a Planted Ditch Constructed for Tertiary Sewage Treatment in Schwaan, Germany International Review of Hydrobiology. 86:241-252.

Krammer K Lange-Bertalot H 1988. Bacillariophyceae. 2. Teil: Bacillariaceae, Epithemiaceae, Surirellaceae In: Ettl, H., J. Gerloff, H. Heynig and D. Mollenhauer (eds.) Susswasserflora von Mitteleuropa, Band 2/2. Gustav Fisher Verlag, Jena.P. 596. 
Krammer K Langebertalot H 1991a. Bacillariophyceae. Tome 3: Centrales, Fragilariaceae, Eunotiaceae. Semper Bonis Artibus. 576 p.

Krammer K. Langebertalot H 1991b. Bacillariophyceae. Tome 4: Achnanthaceae. Semper Bonis Artibus; $437 \mathrm{p}$.

Lange-Bertalot H. Fumanti B. Cavacini P. Tagliaventi N 2009. The genus Navigiolum (Bacillariophyceae) in Mediterranean and North African rock pool habitats: description of four new species from Algeria.Fottea. 9(2): 179-185.

Lavoie I. Hamilton PB. Campeau S. Grenier M. Dillon PJ 2008. Guide d'identification des diatomées des rivières de l'Est du Canada. Presse de l'Université du Québec. 256 p.

Leland, HV. Porter SD 2000. Distribution of benthic algae in the upper Illinois River basin in relation to geology and land use. Freshwater Biology. 44: 279-301.

Lobo EA. Katoh K. Aruga Y. 1995. Response of epilithic diatom assemblages to water pollution in rivers in the Tokyo metropolitan area, Japan. Freshwater Biology. 34: 191-204.

Mansour B. Bessedik M. Saint Martin JP. Belkebir L 2008. Signification paléoécologique des assemblages de diatomées du Messinien du Dahra sud-occidental (bassin du Chélif, Algérie nord-occidentale). Geodiversitas. 30 (1): 117-139.

Negadi M. Hassani A. Ait Hammou M. Dahmani W. Miara MD. Kharytonov M. Zhukov O 2018. Diversity of Diatom epilithons and quality of water from the subbasin of Oued Mina (district of Tiaret, Algeria).Ukrainian Journal of Ecology. 8(1): 103-117.

Nehar B. Blanco S. HadjadjAoul S. 2015. Diversity and ecology of diatoms in northwest of algeria: case of el-hammam stream and estuary of Cheliffriver. Applied Ecology and Environmental Research. 13(1): 37-52.

Nehar B 2016. Contribution à l'étude des diatomées Benthiques de quelques cours d'eau de l'Oranie: taxonomie et écologie. Thèse Doct. Univ. Oran. 227p.

Petit P1895. Catalogue des Diatomées du Maroc, d'Algérie et de Tunisie, Annexe à la flore de Battandier et Trubat-Alger, Jourdan, $52 \mathrm{p}$.

Prateek S. Jyoti V. Sarika G. Ambrina S 2016. On the importance of diatoms as Ecological Indic ators in River Ecosystems: A Review Indian Journal of Plant Sciences. 5 (1) :70-86.

PrygielJ. Coste M 1993. The assessment of water quality in the Artoie-Picardie water basin(France) for the use of diatoms. Hydrobiologia, 269/270: 343-349.

Prygiel J. Coste M 2000. Guide méthodologique pour la mise en oeuvre de l'Indice Biologique Diatomées NF T 90-354. Agences de l'Eau-Cemagref, France, 134 p.

Rimet F 2017. Phytoplancton du léman. The phytoplankton of LakeGeneva.Rapp. Comm. int. prot.Eaux Léman contre pollut., Campagne 2017, 2018. 86-97.

Rimet F 2018. Phytoplancton du léman. The phytoplankton of Lake Geneva. Rapp. Comm. int. prot. Eaux Léman contre pollut. Campagne 2018. 128-139.

Rodier, J., 1996. L'analyse de l'eau : Eaux naturelles, aux résiduaires, eaux de mer. 8ème édition, Dunod, Paris.

Taylor JC. Harding WR. Archibald CGM 2007a., An illustrated guide to some common diatom species from South Africa. Water Research Commission Report. South Africa,

No. 281-07, 200 p.

Taylor JC. Harding WR. Archibald CGM. 2007b. A methods manual for the collection,preparation and analysis of diatom samples.Version 1.0. Water Research CommissionReport, South Africa, No. 282-07, 49p.

Triest L. Kaur P. Heylen S. De Pauw N 2001. Comparative monitoring of diatoms, macroinvertebrates and macrophytes in the Woluwe River (Brussels, Belgium). Aquatic Ecology. 35: 183-194.

Van Dam H. Mertens A. Sinkeldam J 1994. Acoded checklist and ecological indicator Values of fresh water diatoms from The Netherlands. Neth J Aquatic Ecology. 28:117-133.

Ziemann H., Kies L., Schulz C. J., 2001. Desalinization of running waters. III. Changes in the structure of diatom assemblages caused by a decreasing salt load and changing ion spectra in the River Wipper (Thuringia, Germany). Limnologica. 31 (4) : 257-280. 